mgr inż. Damian Goliwąs

dr inz. Tadeusz Jakubowski

dr inz. Marian Kaluba

Instytut Pojazdów Szynowych ,TABOR”

\title{
Inteligentny układ wytwarzania i uzdatniania sprężonego powietrza dla pojazdów trakcyjnych
}

\begin{abstract}
$W$ artykule zaprezentowano uktad wytwarzania i uzdatniania sprężonego powietrza opracowany $i$ wykonany w IPS TABOR, spetniajacy bardzo trudne wymagania eksploatacyjne, stawiane układom pneumatycznym pojazdów trakcyjnych eksploatowanych $w$ naszej strefie klimatycznej. Układ ten tworza: spręzarka, elementy uktadu uzdatniania powietrza i sterownik mikroprocesorowy.

Prace sprężarki w zakresie wymaganego wydatku, temperatury $i$ innych parametrów sprężonego powietrza nadzoruje - na podstawie pomiaru z wieku czujników temperatury i ciśnienia, sterownik mikroprocesorowy. Steruje on również praca układu uzdatniania sprężonego powietrza zapewniającego wysokq jakość sprężonego powietrza dostarczanego do uktadu pneumatycznego pojazdu.

Omówiony uklad wytwarzania $i$ uzdatniania sprężonego powietrza zostat zastosowany w nowych EZT typu EN97 wykonanych dla WKD i dla lokomotywy 111 E.
\end{abstract}

\section{Wstęp}

Sprężone powietrze jest czynnikiem niezbędnym do funkcjonowania pojazdu trakcyjnego. Wytwarzane jest i uzdatniane na pojeździe, w warunkach klimatycznych w jakich eksploatowany jest pojazd.

Aparatura i układy pneumatyczne pojazdu zasilane sprężonym powietrzem stawiają określone wymagania dotyczące ilości i jakości dostarczanego powietrza. Przy uwzględnieniu szerokiego zakresu temperatur eksploatacji pojazdów szynowych w polskiej strefie klimatycznej (T2 zakres $-40^{\circ} \mathrm{C}+35^{\circ} \mathrm{C}$ ), zróżnicowanym zapyleniu i wilgotności pobieranego powietrza oraz drgań występujących na pojeździe, spełnienie stawianych wymagań i niezawodności dostarczania sprężonego powietrza na pojeździe staje się poważnym wyzwaniem inżynierskim.
Należy przede wszystkim zapewnić:

- niezawodne dostarczanie sprężonego powietrza przez sprężarkę z określoną intensywnością zależną od potrzeb w czasie całego życia pojazdu

- dostarczone do układu pneumatycznego pojazdu powietrze w każdych warunkach eksploatacji winno posiadać klasę czystości 2.2.2. (wg ISO 8573-1:2010)

- w ekstremalnych warunkach zimowych doprowadzenie temperatury oleju $\mathrm{w}$ sprężarce przed uruchomieniem do temperatury umożliwiającej bezawaryjne jej uruchomienie

- możliwość regulacji temperatury otoczenia sprężarki, sterownika i układu uzdatniania zarówno zimą jak i latem do poziomu zapewniającego 
optymalną pracę układu

- możliwość automatycznej płynnej regulacji intensywności chłodzenia oleju wychodzącego ze sprężarki zależnie od realizowanej mocy i temperaturowych warunków otoczenia

- uruchamianie zaworów spustu kondensatu z separatora cyklonowego i filtrów $\mathrm{w}$ odpowiednich przedziałach czasowych zarówno dla pracy ciagłej jak i przerywanej sprężarki

- automatyczne zabezpieczenie sprężarki przed nadzwyczajnymi awariami np przez wyłączenie agregatu sprężarkowego $\mathrm{w}$ przypadku przekroczenia dopuszczalnej temperatury oleju

- niski poziom hałasu układu wytwarzania sprężonego powietrza

- izolację sprężarki od drgań i przenoszenia hałasu na pudło.

Spełnienie powyższych wymagań stało się możliwe głównie dzięki zastosowaniu $\mathrm{w}$ opracowanym przez IPS układzie, sterownika mikroprocesorowego. Steruje on praca całego układu według opracowanych algorytmów, na podstawie mierzonych wielkości z wielu czujników pomiarowych stanu oraz współpracujących z nim elementów wykonawczych.

\section{Opis układu wytwarzania i uzdatniania sprężo- nego powietrza}

Omawiany układ wytwarzania i uzdatniania sprężonego powietrza składa się z agregatu sprężarkowego (G) tłoczącego sprężone powietrze poprzez chłodnicę i układ uzdatniania do zbiorników. Pracą agregatu sprężarkowego, chłodnicy i zespołami układu uzdatniania sprężonego powietrza (łącznie ze funkcją ich podgrzewania) oraz ich współpraca, steruje opracowany w IPS sterownik 114ZE $(\mathrm{H})$.

Układ uzdatniania sprężonego powietrza tworzą: separator cyklonowy WSDR25 (C) z elektrozaworem i podgrzewaniem, dwa filtry - wstępny DDR17 (D) i dokładny PDR17 (E) (również z elektrozaworami i ich podgrzewaniem), zawór zwrotny oraz osuszacz membranowy SDR6 (B) z zaworkiem elektropneumatycznym podającym powietrze do odprowadzenia wilgoci z osuszacza podczas pracy.

W pobliżu separatora cyklonowego i filtrów (D, E) znajduje się zbiornik kondensatu (F), do którego spływa kondensat cyklicznie usuwany przez zaworki z separatora cyklonowego i filtrów. Sterowanie tymi zaworami odbywa się ze sterownika wg specjalnego programu. Zbiornik skroplin wyposażony jest w przewód odpowietrzający i zawór bezpieczeństwa wyregulowany na $0,3-0,5$ bar. Posiada on również wskaźnik poziomu zebranego kondensatu, przewód z kurkiem umożliwiający usunięcie skroplin do przygotowanego naczynia (aby następnie poddać go utylizacji) oraz grzałkę. Gdy temperatura otoczenia spadnie poniżej $4{ }^{\circ} \mathrm{C}$ sterownik załącza grzanie filtrów i zbiornika skroplin umożliwiając prawidłową pracę układu w ujemnych temperaturach.

Oczyszczone i osuszone powietrze akumulowane jest w zbiornikach głównych pojazdu.

Widok układu wytwarzania i uzdatniania sprężonego powietrza przedstawiono na rys. 1 .

Układ połączeń elektrycznych zaworów, czujników i elementów grzejnych układu ze sterownikiem przedstawiono na rys. 2

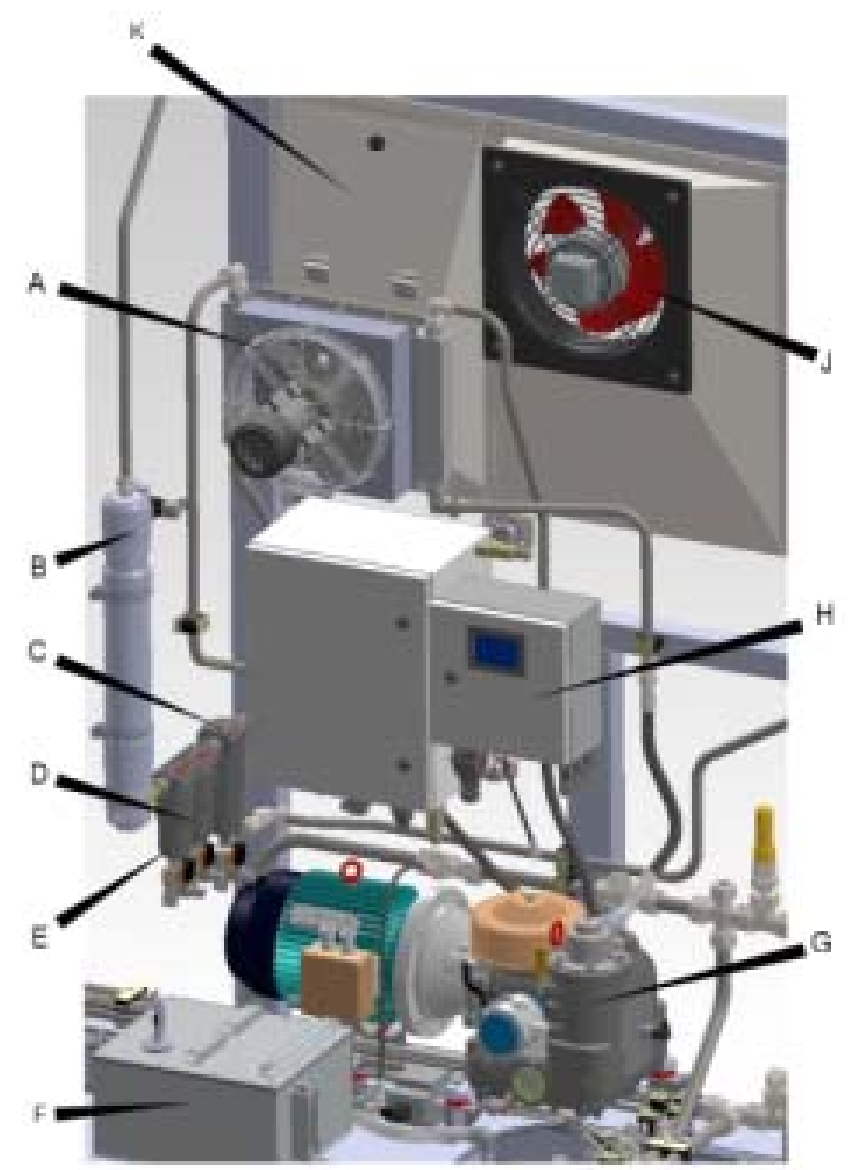

\begin{tabular}{|l|l|l|l|}
\hline A & wentylator chłodnicy & F & zbiornik skroplin \\
\hline B & osuszacz membranowy & G & agregat sprężarkowy \\
\hline C & separator cyklonowy & H & sterownik układu \\
\hline D & filtr wstępny & J & wentylator wyciąowy \\
\hline E & filtr dokładny & & \\
\hline
\end{tabular}

Rys. 1. Układ wytwarzania i uzdatniania sprężonego powietrza 316B1 (33WE)

\subsection{Agregat sprężarkowy}

Agregat sprężarkowy (G) zbudowany jest na bazie śrubowej sprężarki kompaktowej TEMPEST 3 napędzanej silnikiem elektrycznym typu WU-DF 132SJXH P-7,5kW; łapowo-kołnierzowym ; IP55; z uzwojeniem w klasie izolacji $\mathrm{H}$;o regulowanej prędkości obrotowej $(2200 \div 4700 \mathrm{obr} . / \mathrm{min}$.).

Agregat sprężarkowy wyposażony jest w grzałkę zanurzoną w zbiorniku oleju i matę grzewczą zamontowaną na zewnętrznej powierzchni korpusu filtra oleju. 


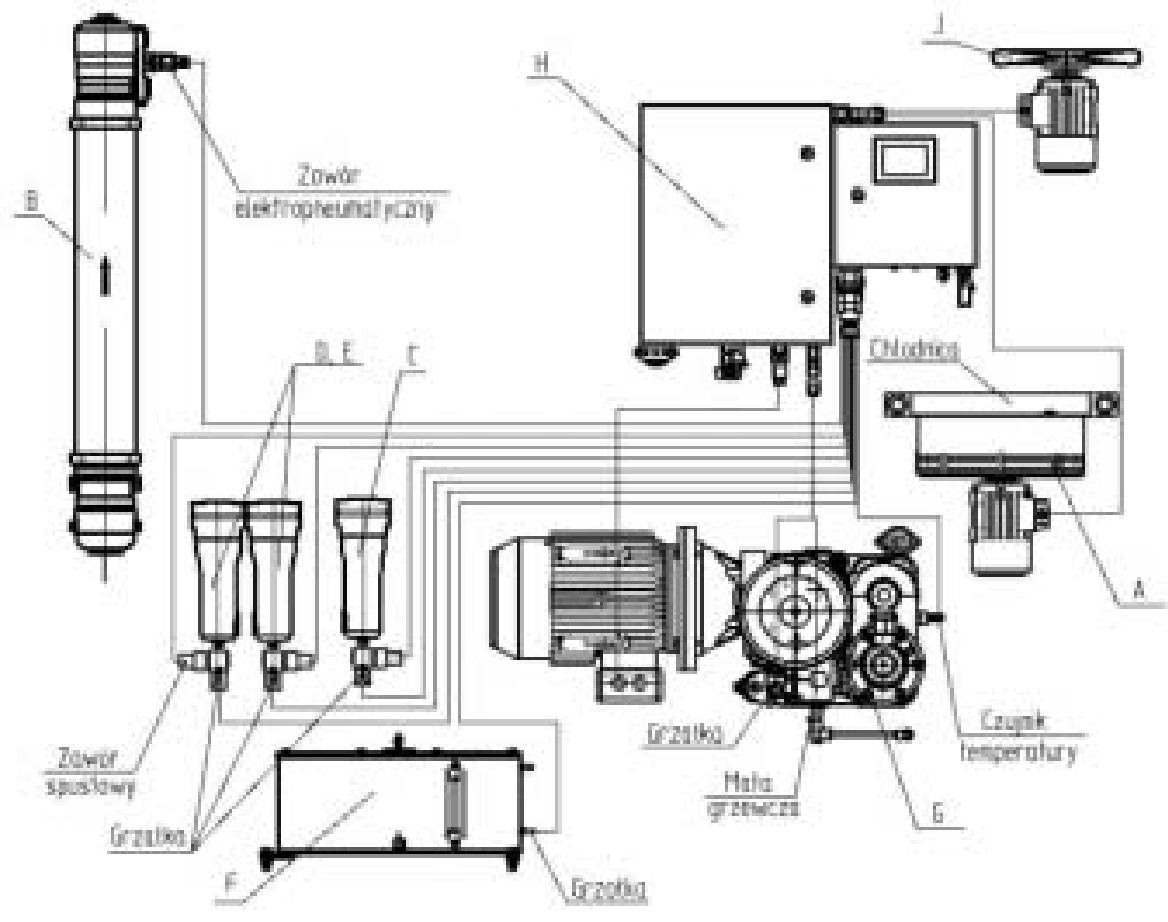

Rys. 2. Połączenia elektryczne w układzie

Stopień sprężarkowy połączono z silnikiem elektrycznym sprzęgłem ROTEX ${ }^{\circledR}$ o specjalnej konstrukcji półsprzęła. Sprzęło jest skrętnie elastyczne i przenosi moment skręcający jako połączenie kształtowe. Dwa półsprzęgła posiadają po wewnętrznej stronie wklęsłe kły. Przestrzeń między nimi wypełnia łącznik elastyczny o zębach ewolwentowych. Łącznik elastycznego sprzęgła ROTEX ${ }^{\circledR}$ narażony jest tylko na nacisk (brak zginania) przez co cechuje go znaczna obciążalność pojedynczego zęba (Rys. 3.).

Agregat sprężarkowy zamocowany jest poprzez wibroizolatory do wsporników na górnej powierzchni ostoi, co izoluje przedostawanie się hałasu silnika elektrycznego i sprężarki, który mógłby być przenoszony materiałowo na pudło pojazdu.

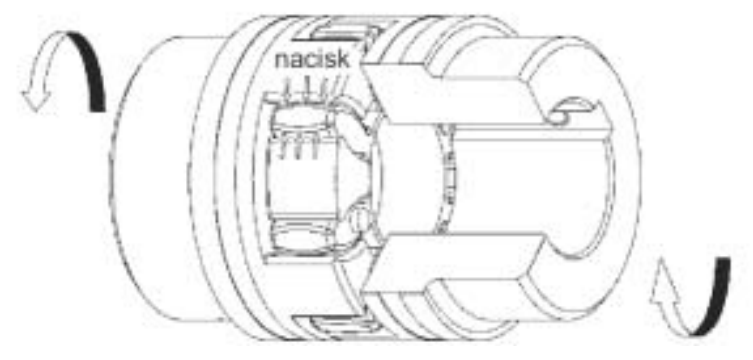

Rys. 3. Obciążenie elastycznego sprzęgła ROTEX ${ }^{\circledR}$

\subsection{Chłodnica powietrza-oleju}

Proces chłodzenia powietrza i oleju realizowany jest przez specjalną chłodnicę wraz z osprzętem skła dającym się $\mathrm{z}$ dwupolowego silnika $3 \times 400$ VAC nape. dzającego wentylator, kanału i osłony wentylatora.
Chłodnica posiada dwie oddzielne sekcje do chłodzenia oleju i chłodzenia sprężonego powietrza $\mathrm{z}$ oddzielnymi podłączeniami. Strumień powietrza odbierający ciepło z obu sekcji chłodnicy wytwarzany jest przez wentylator napędzany silnikiem elektrycznym.

Wentylator jest tak zabudowany, że powietrze jest pobierane z zewnątrz przez chłodnicę $\mathrm{i}$ dalej przez wentylator, co zapewnia pełne wykorzystanie całej powierzchni chłodnicy i tym samym wywołuje skuteczne chłodzenie czynników roboczych sprężarki. Szczególnie istotne jest to latem gdy temperatury otoczenia moga przekroczyć $30^{\circ} \mathrm{C}$.

\subsection{Układ uzdatniania sprężonego powietrza}

\section{Separator cyklonowy}

Separator cyklonowy (C) powoduje usunięcie kondensatu (drobin wody i oleju) ze sprężonego powietrza opuszczającego chłodnicę, poprzez nadanie strumieniowi powietrza ruchu wirującego odrzucającego drobiny kondensatu na ścianki obudowy (Rys. 4.).

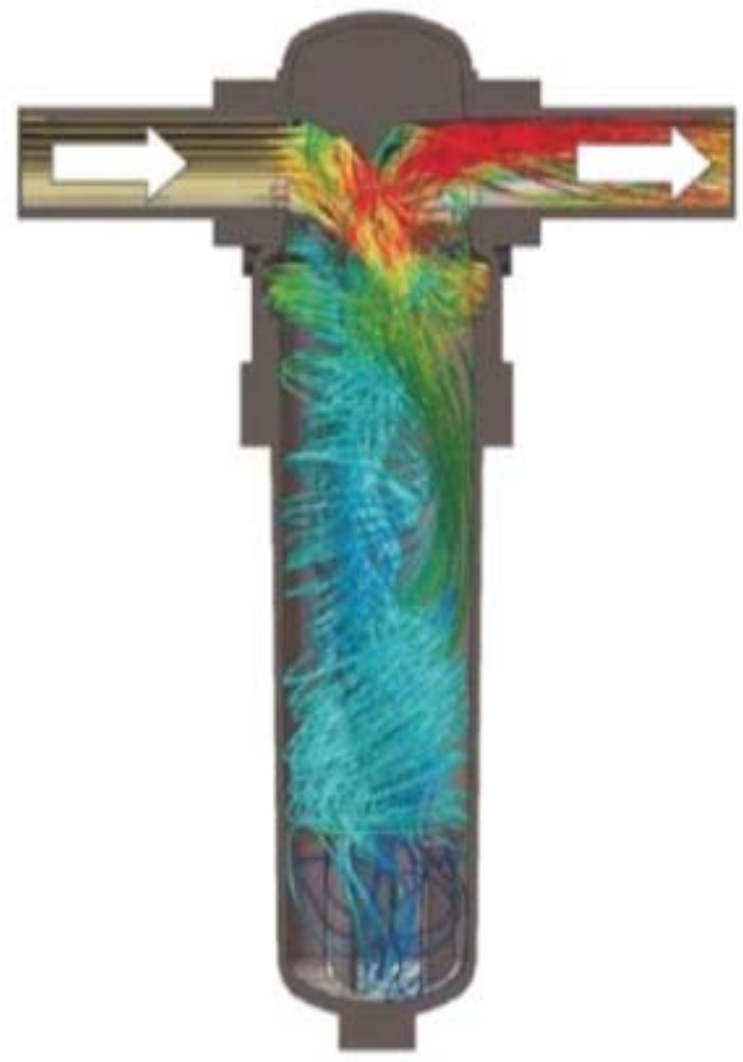

Rys. 4. Separator cyklonowy 
Separator cyklonowy nie posiada wkładu filtrujacego. Kondensat gromadzi się na dnie obudowy separatora cyklonowego, skąd jest cyklicznie usuwany przez zabudowany na nim elektrozawór. Zawór wyposażony jest $\mathrm{w}$ podgrzewacz.

Chociaż separator cyklonowy usuwa większe drobiny skroplin, to sprężone powietrze opuszczające go nie jest na tyle czyste aby mogło być bezpośrednio skierowane na włókna osuszacza membranowego (B). $\mathrm{Z}$ tego powodu pomiędzy separatorem cyklonowym, a osuszaczem membranowym montuje się filtry wstępnego i dokładnego oczyszczania, stanowiące konieczną barierę dla zanieczyszczeń sprężonego powietrza (przede wszystkim maleńkich drobin wody i oleju).

\section{Filtr wstępny}

Filtr wstępny DDR (D) służy do wstępnego usuwania drobin przed osuszaczem membranowym. Zatrzymuje on przede wszystkim cząsteczki wody i oleju, które przedostały się przez separator cyklonowy. Drobiny te zatrzymywane są na wkładzie filtrującym oraz $\mathrm{w}$ formie kondensatu są spuszczane automatycznie przez zabudowany na filtrze zawór elektropneumatyczny do zbiornika skroplin. Zawór wyposażony jest w podgrzewacz

\section{Filtr dokładny}

Filtr dokładny PDR (E) to filtr o wysokiej wydajności do usuwania drobin kurzu, cieczy i aerozolów. Jest instalowany między filtrem DDR (D) a osuszaczem membranowym (B). Wkład filtrujący pochłania drobne cząstki stałe. Mgła wodno-olejowa skrapla się a kropelki te sa zatrzymywane i odprowadzane automatycznie tak jak to opisano powyżej dla filtra DDR.

\section{Osuszacz membranowy}

Osuszacz membranowy (B) składa się z wielu tysięcy włókien polimerowych (stanowiących sito molekularne) umieszczonych $\mathrm{w}$ metalowym korpusie zamkniętym na stałe $\mathrm{z}$ obu stron pokrywami. W jednej pokrywie znajduje się otwór wlotowy sprężonego powietrza do osuszacza poprzedzony zaworem zwrotnym. W drugiej pokrywie znajduje się otwór wylotowy osuszonego sprężonego powietrza do instalacji (Rys. 5.).

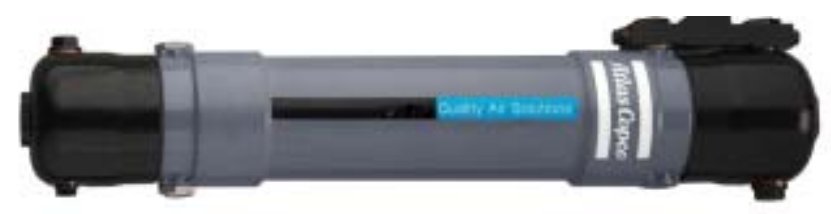

Rys. 5. Osuszacz membranowy

\subsection{Sterownik układu}

Mikroprocesorowy układ wytwarzania i uzdatnia powietrza typu 114ZE (H) służy do sterowania pracą sprężarki, chłodnicy i elementów układu uzdatniania.
Oprócz jednostki CPU, wejściowych i wyjściowych modułów pomiarowo-sterujących, zawiera zabezpieczenia prądowe, falowniki $3 \times 400 \mathrm{VAC}$ do sterowania prędkością obrotową sprężarek i wentylatorów chłodnicy, styczniki do za- i wyłączania obwodów grzewczych: sprężarki, układu uzdatniania sprężonego powietrza i zbiornika skroplin oraz czujniki ciśnień i temperatur.

Wewnątrz skrzynki falowników zabudowana jest grzałka.

Dodatkowo urządzenie wyposażono w dotykowy panel operatorki z zainstalowanym intuicyjnym oprogramowaniem informujący personel o stanach pracy, awariach, motogodzinach, wartościach ciśnień.

\section{Zasada działania układu}

\section{Agregat sprężarkowy}

Sprężarka napędzana jest silnikiem elektrycznym WU-DF 132SJX-H o regulowanej prędkości obrotowej $(2200 \div 4700 \mathrm{obr}$./min.) przez sterownik. Na podstawie pomiarów realizowanych przez czujniki, sterownik ustala wartość chwilowego zapotrzebowania na sprężone powietrze na pojeździe i przy pomocy falownika realizuje płynne sterowanie wydajnością sprężarki $\left(27 \div 58 \mathrm{~m}^{3} / \mathrm{h}\right)$.

Agregat sprężarkowy przeznaczony jest do pracy przerywanej lub ciagłej $\mathrm{w}$ bardzo szerokim zakresie temperatur otoczenia $\left(-40 \div+40{ }^{\circ} \mathrm{C}\right)$. W zasadzie podczas eksploatacji ezt, agregat sprężarkowy pracuje $\mathrm{w}$ trybie przerywanym, choć przy dużych nieszczelnościach może również pracować w sposób ciagły.

W pojeździe 33WE (WKD) zabudowane są dwa główne agregaty sprężarkowe.

Pracują one $\mathrm{w}$ jednym $\mathrm{z}$ dwóch trybów pracy:

- jako sprężarka „podstawowa”

- jako sprężarka „dodatkowa”.

Tryb pracy uzależniony jest od sygnału z aktywnej kabiny. Jeżeli sprężarka znajduje się po stronie aktywnej kabiny, pracuje jako sprężarka „dodatkowa”, jeśli natomiast sprężarka znajduje po stronie nieaktywnej kabiny pracuje jako sprężarka „podstawowa”.

Sprężarka „podstawowa” pracuje w zakresie ciśnień 0$850 \mathrm{kPa}$. Wyłączenie sprężarki następuje po osiągnięciu ciśnienia w zbiorniku głównym $850 \mathrm{kPa}$. Ponowne załączenie sprężarki następuje jeśli w zbiorniku głównym ciśnienie wyniesie $700 \mathrm{kPa}$ lub mniej.

W przypadku gdy podczas eksploatacji pojazdu w instalacji pneumatycznej ciśnienie spadnie ze względów nadzwyczajnych poniżej $580 \mathrm{kPa}$ lub podczas napełniania próżnego układu pneumatycznego pojazdu, pracę podejmuje również „dodatkowy” agregat sprężarkowy. Po osiagnięciu w instalacji ciśnienia 680 kPa agregat „dodatkowy” zostaje wyłączony, a dalsze napełnianie zbiorników do ciśnienia $850 \mathrm{kPa}$ realizuje agregat ,podstawowy”. 
W trakcie normalnej eksploatacji (brak nadmiernego zapotrzebowania na sprężone powietrze), pracuje jedynie agregat ,podstawowy”. Wyjątek stanowi sytuacja, gdy sprężarka ta awaryjnie osiagnie temperaturę pracy powyżej $100^{\circ} \mathrm{C}$. Wówczas będzie ona zatrzymana, a jako sprężarka „podstawowa” załączony zostanie agregat sprężarkowy znajdujący się za aktywną kabiną maszynisty. Ponowne załączenie wyłączonego agregatu sprężarkowego, który osiagnął $100^{\circ} \mathrm{C}$, następuje po jego ostygnięciu do temperatury około $70^{\circ} \mathrm{C}$. Fakt ten jest przekazywany do systemu diagnostycznego pojazdu oraz wyświetlany jest na pulpicie sterującym maszynisty. Niemniej dzięki takiemu rozwiązaniu możliwa jest awaryjna eksploatacja pojazdu (brak konieczności natychmiastowego wyłączenia pojazdu z ruchu), gdyż mimo to zapewnione jest sprężone powietrze na pojeździe. Wzrost temperatury do poziomu $100^{\circ} \mathrm{C}$ nie jest normalną sytuacją eksploatacyjną i jest wynikiem dużego zanieczyszczenia chłodnicy lub awarii wentylatora chłodnicy. Przyczyna przegrzewania się agregatu sprężarkowego musi być zdiagnozowana i usunięta $\mathrm{w}$ najbliższym czasie przez obsługę serwisową pojazdu.

Optymalną temperaturą pracy agregatu sprężarkowego (ze względu na żywotność agregatu, żywotność oleju, parametry smarne i antykorozyjne oleju oraz jakość sprężanego powietrza) jest temperatura oleju sprężarki $60 \div 80^{\circ} \mathrm{C}$.

Gdy temperatura oleju jest niższa niż ok. $70^{\circ} \mathrm{C}$ zawór termostatyczny sprężarki jest zamknięty i olej w agregacie przepływa w tzw. krótkim obiegu, tzn. z pominięciem chłodnicy.

Termostat zamykając i otwierając się, zapewnia we współpracy z chłodnicą, właściwą (optymalną) temperaturę pracy agregatu sprężarkowego. Gdy temperatura oleju jest większa niż $70{ }^{\circ} \mathrm{C}$ otwiera się płynnie zawór termostatyczny i olej płynie do chłodnicy, skąd po schłodzeniu i przejściu przez filtr oleju kierowany jest $\mathrm{z}$ powrotem do zbiornika oleju agregatu sprężarkowego.

W celu osiagnięcia optymalnych parametrów pracy sprężarki, sterownik, tak płynnie steruje silnikiem, wentylatorem chłodnicy, ogrzewaniem i zaworem ssącym (sterowanym elektropneumatycznie), by jak najszybciej osiagnąć i utrzymywać właściwe parametry pracy agregatu sprężarkowego.

Jeżeli temperatura oleju po uruchomieniu sprężarki nie osiagnęła 60 stopni a ciśnienie w zbiorniku głównym wynosi już $850 \mathrm{kPa}$, następuje zamknięcie zaworu ssania, przejście na średnie uzyskać wzrost temperatury do poziomu optymalnego. Silnik w tym trybie pracuje do momentu osiagnięcia przez olej 60 stopni lub przez czas 10 minut. Po spełnieniu tych warunków następuje otwarcie zaworu ssania, odblokowanie pracy chłodnicy, załączanie zaworów i tłoczenie sprężonego powietrza do zbiornika głównego do poziomu ciśnienia $850 \mathrm{kPa}$. Podczas sytuacji opisanej wyżej, gdy zawór ssania jest zamknięty i wystapi szybki spadek ciśnienia w zbiorniku głównym pojazdu (poniżej progu $700 \mathrm{kPa}$ ), następuje otwarcie zaworu ssania.

Sprężarka główna działająca jako ,dodatkowa" na pojeździe WKD, pracuje analogicznie jak sprężarka „podstawowa” $\mathrm{z}$ tym, że zakres ciśnień w którym podejmuje prace wynosi $0-750 \mathrm{kPa}$. Wyłączenie następuje po osiągnięciu na zbiorniku głównym ciśnienia $750 \mathrm{kPa}$. Ponowne załączenie sprężarki dodatkowej wystąpi jeśli na zbiorniku głównym ciśnienie spadnie poniżej $650 \mathrm{kPa}$.

Agregat sprężarkowy wyposażony jest w grzałkę zanurzoną w zbiorniku oleju i mate grzewczą zamontowaną na zewnętrznej powierzchni korpusu filtra oleju. Jeśli sterownik 114ZE wykryje zbyt niską ujemną temperaturę oleju następuje założenie czasowej blokady na start silnika sprężarki i załączenie grzałek. Gdy temperatura oleju wynosi poniżej $-30^{\circ} \mathrm{C}$, załączana jest grzałka oleju i mata grzewcza na filtrze. Po upływie 15 minut następuje wyłączenie grzałki oleju oraz maty grzewczej i następuje zezwolenie na uruchomienie silnika sprężarki. Gdy temperatura oleju mieści się w przedziale od $-30^{\circ} \mathrm{C}$ do $-15^{\circ} \mathrm{C}$ załączana jest również grzałka oleju i mata grzewcza na filtrze a po upływie 7 minut następuje wyłączenie grzałki oleju oraz maty grzewczej i następuje zezwolenie na uruchomienie sprężarki. W wyższych temperaturach (powyżej $-15^{\circ} \mathrm{C}$ ) nie zostaje założona blokada na start silnika sprężarki oraz nie zostają załączone grzałki i uruchomienie sprężarki następuje od razu. Blokada startu silnika sprężarki i podgrzewanie oleju sygnalizowane jest na panelu operatorskim sterownika oraz informacja ta jest wysyłana po magistrali danych do sterownika pojazdu.

W układzie zastosowano dwa czujniki pomiarowe ciśnienia. Jeden mierzy ciśnienie w separatorze oleju sprężarki, drugi ciśnienie w zbiorniku głównym pojazdu. Na podstawie tych ciśnień sterownik diagnozuje stan zanieczyszczenia separatora i filtrów oraz dobiera wydatek sprężarki na takim poziomie, że umożliwia warunkową eksploatację układu. Pomiar temperatury oleju, dokonywany jest dwoma niezależnymi torami pomiarowymi przy pomocy podwójnego czujnika Pt100, który mierzy temperaturę oleju w zbiornika oleju (redundancja: sprężarka może normalnie pracować z jednym uszkodzonym torem pomiarowym czujnika temperatury oleju).

O parametrach pracy sprężarki i awariach czujników informuje sterownik na swoim wyświetlaczu lub wyświetlacz na pulpicie, który otrzyma te informacje od sterownika 114ZE przez magistralę danych pojazdu.

\section{Chłodnica}

Załączenie wentylatora chłodnicy podczas pracy sprężarki następuje w określonych

warunkach: 
- gdy temperatura otoczenia jest dodatnia oraz temperatura oleju wynosi powyżej 50 stopni

- gdy temperatura otoczenia jest ujemna i temperatura oleju wynosi powyżej 60 stopni

W celu dopasowania wydajności cieplnej zespołu chłodnicy do obciążenia sprężarki, napęd wentylatora chłodnicy odbywa się ze zmienną prędkością obrotowa. Realizowane jest przez falownik silnika wentylatora sterowany przez sterownik na podstawie mierzonych temperatur.

Kanał, na którym jest zabudowana chłodnica posiada otwierany na czas zimy upust, dzięki czemu wentylator nie pobiera zimnego powietrza bezpośrednio $\mathrm{z}$ zewnątrz. Zapewnia to dodatkowo podgrzewanie przedziału maszynowego w okresie zimy co stwarza lepsze warunki pracy sprężarki szczególnie w przypadku pracy przerywanej.

\section{Separator cyklonowy}

Z separatora cyklonowego kondensat jest cyklicznie usuwany przez zabudowany na nim normalnie otwarty elektrozawór (w pracy przerywanej sprężarki po zatrzymaniu pracy sprężarki, a podczas pracy ciągłej sprężarki w określonych interwałach czasowych). Zawór ten sterowany jest przez sterownik. Zawór wyposażony jest $\mathrm{w}$ podgrzewacz, który $\mathrm{w}$ przypadku temperatury zewnętrznej mniejszej niż $4{ }^{\circ} \mathrm{C}$ zostaje automatycznie włączony chroniąc zawór przed zamarzaniem i utratą drożności.

\section{Filtry}

Normalnie otwarte zawory spustu kondensatu z filtrów wstępnego i dokładnego uruchamiane są przez sterownik. Zawory również wyposażone są $\mathrm{w}$ podgrzewacz, który w przypadku temperatury zewnętrznej mniejszej niż $4{ }^{\circ} \mathrm{C}$ zostaje automatycznie włączony chroniąc zawór przed zamarzaniem i utratą drożności.

Wyłączenie (zdjęcie napięcia z cewek) zaworów cyklonu i filtrów następuje po około 30 sekundach od momentu wyłączenia silnika sprężarki. Po tym czasie uruchamiana jest sekwencja załączania i wyłączania zaworów w celu wydalenia z nich kondensatu.

\section{Osuszacz}

Oczyszczone ale wilgotne sprężone powietrze (bez oleju, wody i cząsteczek stałych) wpływa do pokrywy wlotu. Powietrze przepływa przez pory włókien polimerowych. Wskutek różnicy w ciśnieniu cząsteczkowym, molekuły pary wodnej przenikają przez polimer. Suche powietrze przepływa dalej i wypływa przez pokrywę wylotu.

Niewielka ilość osuszonego już powietrza $(10 \div 15 \%)$ jest zawracana i wykorzystywana w charakterze powietrza regenerującego (osuszającego), wytwarzającego różnicę w ciśnieniu cząsteczkowym na włóknach polimerowych. Przepływa ono przez dyszę wewnątrz kanału powietrznego i opływa włókna z zewnątrz. Suche powietrze regenerujące, zabiera cząstki pary zebrane $\mathrm{z}$ zewnętrznych powierzchni włókien, przepływa $\mathrm{w}$ kierunku przeciwnym do strumienia osuszanego i wilgotne wypływa do atmosfery $z$ osuszacza membranowego przez otwory odpowietrzające usytuowane w dolnej części obudowy.

Osuszacz membranowy jest wyposażony w zawór elektropneumatyczny do załączenia przepływu powietrza regenerującego. Gdy sprężarka zaczyna pracować, zawór elektropneumatyczny jest zasilany i następuje jego otwarcie, co umożliwia przepływanie powietrza regenerującego przez zawór i dalej przez zewnętrzne powierzchnie włókien osuszających. W przypadku zatrzymania sprężarki zasilanie zaworu zostaje przerwane a przepływ powietrza odcięty.

\section{Sterownik}

Praca układu wytwarzania i uzdatniania sprężonego powietrza jest inteligentnie sterowana mikroprocesorowym sterownikiem na podstawie wykonywanych przez niego pomiarów wielu parametrów. Sterowanie parametrami pracy układu uzdatniania sprężonego powietrza i agregatu sprężarkowego realizuje opracowany w IPS Tabor sterownik 114ZE (H). Sterownik również realizuje eksploatacyjne za- i wyłączenia agregatu sprężarkowego zgodnie z algorytmem sterowania układem wytwarzania i uzdatniania. Sterownik działa na podstawie pomierzonych parametrów zewnętrznych (ciśnień i temperatur) i steruje zewnętrznymi urządzeniami wykonawczymi układu (falowniki, styczniki, silniki, zawory elektropneumatyczne, grzałki, siłowniki pneumatyczne). Dzięki temu samoczynnie układ dostosowuje się do zmieniających się warunków eksploatacji zapewniając optymalne warunki pracy całego układu, jego bezawaryjna prace oraz diagnostykę dostępną z wyświetlacza sterownika jak również z poziomu panelu operatorskiego maszynisty.

Na przykład, jeżeli temperatura wewnątrz skrzynki falowników spadnie poniżej $+10^{\circ} \mathrm{C}$ następuje załączenie grzałki zabudowanej wewnątrz skrzynki falowników, grzanie trawa tak długo aż temperatura wzrośnie powyżej $+10^{\circ} \mathrm{C}$. W sytuacji skrajnej gdy temperatura wewnątrz skrzynki falowników spadnie poniżej $20^{\circ} \mathrm{C}$ następuje zablokowanie startu silnika sprężarki na okres 7 minut załączana jest grzałka, która grzeje wnętrze do temperatury powyżej $+10^{\circ} \mathrm{C}$.

Użytkownik komunikuje się z sterownikiem całego układu za pomoca panelu wyświetlacza LCD, zabudowanego w obudowie sterownika: wyświetlane są informacje o parametrach pracy układu sprężarki i o ewentualnych jego nieprawidłowościach w działaniu.

W celu osiagnięcia optymalnych parametrów pracy, sterownik, płynnie steruje silnikiem, wentylatorem chłodnicy, ogrzewaniem i zaworem ssącym sprężarki (sterowanym elektropneumatycznie), by jak najszybciej osiągnąć i utrzymywać w czasie eksploatacji wła- 
ściwe parametry pracy agregatu sprężarkowego.

\section{Ujemna temperatura otoczenia}

Jeśli temperatura otoczenia spadnie poniżej $4^{\circ} \mathrm{C}$ stopni następuje załączenie grzałek rezystancyjnych cyklonu, filtra wstępnego i dokładnego oraz załączenia grzałki zbiornika skroplin w celu nie dopuszczenia do zamarznięcia kondensatu. Wyłączenie grzania zaworów i zbiornika skroplin następuje powyżej $4^{\circ} \mathrm{C}$ temperatury otoczenia.

\section{Praca wentylatora przedziału maszynowego}

Wentylator przedziału maszynowego załączany jest wówczas gdy temperatura otoczenia (przedziału) jest większa od $+30^{\circ} \mathrm{C}$ lub temperatura skrzynki falowników wzrosła powyżej $+40^{\circ} \mathrm{C}$. Wentylator wyłączany jest gdy temperatura otoczenia spadnie poniżej $30^{\circ} \mathrm{C}$ lub temperatura skrzynki falowników spadnie poniżej $+40^{\circ} \mathrm{C}$.

\section{Zakończenie}

Zaprezentowany wyżej układ wytwarzania i uzdatniania sprężonego powietrza spełnił wymagania stawiane układom zasilania pojazdów trakcyjnych $\mathrm{w}$ sprężone powietrze.
Osiągnięto to dzięki zastosowaniu sprężarki o regulowanym wydatku sprężanego powietrza i innych elementów układu, sterowanych sterownikiem mikroprocesorowym $114 \mathrm{ZE}$ działającym wg opracowanego algorytmu na podstawie mierzonych parametrów zewnętrznych przez sterownik. Wyżej przedstawiony układ w pełni zabezpiecza zasilanie pojazdu w wymaganą ilość sprężonego powietrza o określonej klasie czystości, niezależnie od szerokiego zakresu warunków zewnętrznych i temperatur otoczenia.

Układ ten (sprężarka wraz z układem sterowania) został poddany badaniom na stanowiskach badawczych w IPS pod kątem pomiaru regulowanego wydatku sprężarki przy różnych parametrach zasilania i w całym zakresie spodziewanych parametrów eksploatacyjnych, w tym także w skrajnych temperaturach $35^{\circ} \mathrm{C} \mathrm{i}+40^{\circ} \mathrm{C}$ w komorze termicznej .

Po uzyskaniu pomyślnych wyników układ został zabudowany $\mathrm{w}$ elektrycznych zespołach trakcyjnych 33WE (typu EN97) wykonanych przez Pesę Bydgoszcz dla WKD, gdzie również pomyślnie przeszedł próby eksploatacyjne. Również w nowobudowanej przez Pesę Bydgoszcz lokomotywie 111E zastosowano wypróbowany na 33WE inteligentny system sterowania wytwarzaniem i uzdatnianiem sprężonego powietrza. 